\section{Spondylurus powelli (Anguilla Bank Skink).} Reproduction.

Date of observation: 13 June 2012. Location: Saint-Barthélemy; Lurin. Coordinates: 17.891806, -62.842917. Voucher: image. On 5 June 2012, a female was captured in the district of Lurin. Seeing that she was pregnant, she was held in captivity. The female's weight at the time of capture was $9 \mathrm{~g}$, SVL $70 \mathrm{~mm}$ (mass to the nearest $0.5 \mathrm{~g}$, length to the nearest $\mathrm{mm}$ ). On 13 June 2012, she give birth to three young: SVL $34 \mathrm{~mm}, 1 \mathrm{~g} ; 34$ $\mathrm{mm}, 0.5 \mathrm{~g} ; 36 \mathrm{~mm}, 1 \mathrm{~g}$. Maternal weight after delivery was 6 g. A few minutes after birth, young and mother ate termites, although the female had refused to eat three days earlier. This is the first report of reproduction in this species.

Karl Questel, La Réserve Naturelle de Saint-Barthélemy, BP 683 Gustavia, 97099 Saint-Barthélemy Cedex, sciencenaturestbarth@gmail.com and Jennifer Boggio, asso.alsophis@gmail.com.
Citation: Questel K, Boggio J. 2012. Spondylurus powelli (Anguilla Bank Skink). Reproduction. Caribbean Herpetology 35:1.

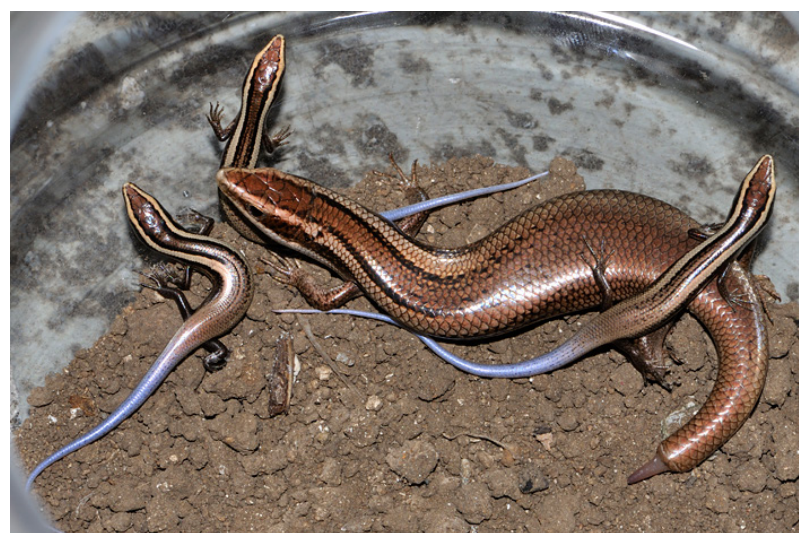

